\title{
Opieka zdrowotna w Polsce w latach 1989-2000
}

\section{Health care in Poland in 1989-2000}

\author{
Jacek Kotuta ${ }^{1 凶}$, Andrzej Kierzek $^{2}$ \\ ${ }^{1}$ Uniwersytet Zielonogórski, Zakład Zdrowia Publicznego, ul. Zyty 28, 65-046 Zielona Góra \\ University of Zielona Góra, Department of Public Health \\ ${ }^{2}$ Karkonoska Państwowa Szkoła Wyższa, Zakład Fizjoterapii, ul. Lwówecka 18, 58-503 Jelenia Góra \\ Karkonosze College in Jelenia Góra, Department of Physiotherapy \\ $\triangle$ j_kotula@poczta.onet.pl
}

\begin{abstract}
A reform of the health care system in 1989-2000 began with the principal changes of the political and economic systems. The changes advanced slowly in the badly-organized health care system, which increased public dissatisfaction. Furthermore, the chronic underfunding of health care forbade the implementation of remedial measures. The principal role in the reform was the passing of the law on health care institutions (1991). The law had both advantages and disadvantages, but in a radical way began and accelerated work on further reformative activities. Work on the preparation of the substantive background to autonomize the health care institutions (budgetary units) and on the draft of the law on general medical insurance continued.

The law on health care institutions has led, for example, to the implementation of cost accounting in public health care
\end{abstract}

institutions and the possibility of transferring some health care tasks to local authorities. The new law also provided foundations for further changes in the health care system, and till now it is the priority legislation for the operation of health care in Poland. As the reform of the health care system progressed the problems of the dehumanization of medicine increased. Sick patients in need of medical help were now perceived as elements of a complicated system ruled by scores and accounts. They became hostages of the health fund, which did not ensure full financing of health care benefits, and of health care personnel, who did not receive funds for non-standard treatments and therefore restricted access to health care services, in some cases even refusing to provide treatment. Unfortunately, the problem of dehumanization in medicine is still significant.

Keywords: history of medicine; history of health care in Poland.

\section{ABSTRAKT}

Reforma systemu ochrony zdrowia w latach 1989-2000 zapoczątkowana została zasadniczymi zmianami ustroju politycznego i gospodarczego. Zmiany i tak źle funkcjonującego systemu opieki zdrowotnej postępowały wolno, co spowodowane było rosnącym niezadowoleniem społecznym. W dodatku chroniczne niedofinansowanie opieki zdrowotnej uniemożliwiało podejmowanie działań naprawczych. Należy odnotować znaczenie uchwalenia ustawy o zakładach opieki zdrowotnej (1991), która miała zarówno wady, jak i zalety, ale w radykalny sposób zapoczątkowała i przyspieszyła prace nad dalszymi działaniami reformatorskimi.

Trwały prace nad przygotowaniem podstaw merytorycznych do usamodzielnienia zakładów opieki zdrowotnej (z jednostek budżetowych) oraz prace nad projektem ustawy o powszechnym ubezpieczeniu zdrowotnym.

Konsekwencją ustawy o zakładach opieki zdrowotnej było m.in. wprowadzenie rachunku kosztów w publicznych zakładach

opieki zdrowotnej oraz możliwość przejęcia części zadań ochrony zdrowia przez samorządy lokalne. Była ona również podstawą do przeprowadzenia kolejnych zmian w sektorze zdrowotnym i dotychczas ma priorytetowe znaczenie dla organizacji ochrony zdrowia w Polsce.

W reformie systemu opieki zdrowotnej narastały problemy dehumanizacji medycyny. Pacjent, będący chorym, potrzebującym pomocy człowiekiem, zaczął być postrzegany jako element złożonego systemu punktowo-przeliczeniowego. Został zakładnikiem z jednej strony systemu Kas Chorych, który nie zabezpieczał pełnego finansowania świadczeń zdrowotnych, z drugiej zaś pracowników ochrony zdrowia, którzy nie otrzymując środków za dodatkowe zabiegi, ograniczali dostęp do świadczeń zdrowotnych, odmawiając niejednokrotnie wykonania zabiegu. Niestety problem dehumanizacji nadal ulega pogłębieniu.

Słowa kluczowe: historia medycyny; historia opieki zdrowotnej w Polsce.

Niezadowolenie społeczne z niesprawności systemu komunistycznego, kryzys ekonomiczny, odejście przez rządzących od głębokich reform systemowych i politycznych schyłku lat 70. i 80. XX w. doprowadziły do zapoczątkowanych 4 czerwca 1989 r. obrad Okrągłego Stołu i pierwszych częściowo wolnych wyborów do parlamentu. Zmiana sytuacji politycznej

miała rozpocząć oczekiwane od lat reformy systemu opieki zdrowotnej, który w czasach Polski Rzeczypospolitej Ludowej był modyfikacją modelu Siemaszki, zwanego od nazwiska sowieckiego komisarza ludowego Nikołaja Aleksandrowicza Siemaszki, obowiązującego od 1948 r. W myśl założeń system był oparty na zasadach całkowitej odpowiedzialności państwa 
za zdrowie społeczeństwa i obejmował pełną opieką zdrowotną wszystkich mieszkańców kraju. Niereformowany od lat 50. XX w., wymagał głębokich zmian o charakterze systemowym [1].

Przy braku wzrostu finansowania świadczeń zdrowotnych na poziomie, który zabezpieczałby możliwość realizacji celów ochrony zdrowia, oraz przy braku analizy rzeczywistych potrzeb zdrowotnych mieszkańców, dążenia państwa do zapewnienia kompleksowej opieki zdrowotnej wszystkim mieszkańcom Polski powodowały konieczność gruntownych reform sektora ochrony zdrowia [2].

Podjęte prace miały dotyczyć m.in. skrócenia czasu oczekiwania na porady lekarskie i konsultacje specjalistyczne, zapewnienia możliwości łatwiejszego dostępu do lecznictwa szpitalnego, spadku korupcjogenności w ochronie zdrowia i poprawy relacji lekarz-pacjent (zmiana z przedmiotowości na podmiotowość) [3]. Skuteczne i celowe zmiany miały poprawić działalność podmiotów służby zdrowia, wpływając na poprawę stanu zdrowia ludności $[2,4]$.

W II połowie lat 80. i w latach 90. XX w. można było zauważyć pewną dynamikę cząstkowych zmian, za pomocą których próbowano dostosować system opieki zdrowotnej do gospodarki rynkowej, przez co w pewnym zakresie stała się możliwa częściowa poprawa warunków pracy i gratyfikacji finansowej pracowników ochrony zdrowia [5].

Oczekiwania społeczne nawiązywały do przedwojennego systemu podstawowej opieki zdrowotnej opartego na instytucji lekarza domowego, którego funkcję w nowej rzeczywistości pełnił lekarz rodzinny - specjalista medycyny rodzinnej. Konieczne stało się usprawnienie działalności systemu ochrony zdrowia w zakresie:

- zaspokajania potrzeb zdrowotnych,

- niedopuszczenia do pogorszenia zdrowia poprzez dbanie o czystość środowiska naturalnego,

- zapewnienia odpowiedniej jakości wody, powietrza i żywności,

- zabezpieczenia interesów zdrowotnych populacji,

- prawa do swobodnego wyboru preferowanej formy podstawowej opieki zdrowotnej, lekarza i pielęgniarki,

- prawa do bezpłatnych świadczeń zdrowotnych,

- pełnej dostępności i ciągłości usług medycznych na najwyższym poziomie,

- prawa do informacji o stanie zdrowia $[2,6]$.

Gwarantem realizacji potrzeb pacjentów stali się lekarze rodzinni. Otrzymując stawkę kapitacyjną za zapisanego pacjenta, mieli prowadzić jego leczenie wraz z finansowaniem zleconych przez siebie badań dodatkowych, które uznali za stosowne. Wprowadzanie reformy wiązało się z zapewnieniami, że pacjentowi w nowym systemie będzie należało się wszystko, bez ograniczeń. Natomiast kontrakty podpisywane z podmiotami leczniczymi zobowiązywały lekarzy do informowania o zgoła odmiennej rzeczywistości.

Jednym z założeń proponowanych reform było przeniesienie kompetencji planowania i zarządzania placówkami ochrony zdrowia do jednostek samorządu terytorialnego oraz zmniejszenie roli planowania centralnego [2, 7]. Jednym z motywów reformy było wprowadzenie do systemu ochrony zdrowia elementów mechanizmów rynkowych. W myśl założeń to rynek miał być gwarantem poprawy jakości i efektywności. Za wzrostem jakości miał podążać wzrost finansowania opieki zdrowotnej, co miało dawać nadzieję na poprawę warunków ekonomicznych pracowników ochrony zdrowia [5].

Ograniczenia możliwości pełnego finansowania świadczeń opieki zdrowotnej w związku z deficytem budżetowym i szybkim tempem rozwoju nauk medycznych łączyły się z propozycjami partycypowania pacjenta w kosztach realizacji świadczeń zdrowotnych. Wyłączenie z tej zasady obejmowało: inwalidów [5], kobiety w ciąży i połogu oraz dzieci i młodzież. Takie propozycje były odpowiedzią na dotychczas obserwowaną fikcyjność w pełni bezpłatnej opieki zdrowotnej i na zjawiska korupcjogenne, które umożliwiał dotychczasowy system [2, 8].

W 1989 r. w związku z ustawicznym niedofinansowaniem świadczeń zdrowotnych wprowadzono pojęcie koszyka świadczeń gwarantowanych. Z założenia miał on określać sposoby postępowania medycznego zgodne z podstawową wiedzą medyczną, określane jako standard postępowania, które za względnie niską cenę prowadziłyby do efektywnej poprawy stanu zdrowia. Zabiegi standardowe miały być opłacane ze środków publicznych, natomiast zabiegi, których nie zapisano w koszyku świadczeń gwarantowanych, nazwane zostały ponadstandardowymi. Świadczenia te miały być opłacane ze środków własnych pacjenta lub być realizowane $\mathrm{z}$ dodatkowego ubezpieczenia indywidualnego albo grupowego [2]. Dopiero od 1997 r. w niektórych dziedzinach medycznych podejmowano próby systematyzowania standardów medycznych, będących podstawą do określenia koszyka świadczeń standardowych gwarantowanych przez państwo, co jednak nie udało się do dzisiaj. Próby wprowadzenia współpłacenia pacjenta za zabiegi ponadstandardowe lub użycie materiałów ponadstandardowych w początkowym okresie zostały przychylnie przyjęte przez środowiska medyczne, jednakże przy braku otwarcia systemu ochrony zdrowia dla wszystkich chętnych uczestników, szybko stały się narzędziem dyskryminującym jednostki prywatnej służby zdrowia i narzędziem niesprawiedliwości społecznej. Z tego powodu możliwość współpłacenia została wycofana na rzecz wyboru metody w całości refundowanej przez system ubezpieczeniowy bądź świadczenia w całości finansowanego ze środków własnych pacjenta.

Podstawowym aktem prawnym, na którym opierało się funkcjonowanie zakładów opieki zdrowotnej w Polsce od 1989 r., było rozporządzenie Ministra Zdrowia i Opieki Społecznej z 2 maja 1989 r. zmieniające rozporządzenie w sprawie organizacji i zadań zakładów opieki zdrowotnej [9]. Zgodnie z nim do jednostek organizacyjnych służby zdrowia należały: przychodnie rejonowe, przychodnie przemysłowe przyzakładowe i międzyzakładowe, przychodnie dla studentów, przychodnie specjalistyczne, szpitale obwodowe, obwodowe stacje pogotowia ratunkowego, żłobki i domy małego dziecka [9].

Kolejnym aktem prawnym reformującym system opieki zdrowotnej była ustawa o samorządzie terytorialnym, która decentralizując dotychczasowy sposób zarządzania, 
wprowadziła gminę jako podstawową jednostkę strukturalną samorządu terytorialnego. Na gminie spoczęła odpowiedzialność za zadania związane z organizacją, funkcjonowaniem i finansowaniem opieki zdrowotnej [10]. Zadania przejęte od administracji centralnej gminy realizowały poprzez prowadzenie jednostek służby zdrowia podporządkowanych dotychczas radom narodowym i organom administracji publicznej działającym na terenie dużych miast $[2,11]$. Bezpośrednim skutkiem tych przepisów było przejęcie przez gminy odpowiedzialności za zakłady opieki zdrowotnej (ZOZ) [2].

Pomimo że gminy przejęły odpowiedzialność za ZOZ-y, koordynacją działań w zakresie ochrony zdrowia zajmował się wojewoda. Jako przedstawiciel rządu dysponował on budżetem przeznaczonym na ochronę zdrowia, przez co ustalał priorytety obowiązujące w tym sektorze na terenie województwa. Oznaczało to tworzenie, przekształcanie i likwidowanie instytucji zdrowotnych [2]. W gestii wojewody znajdowały się również środki finansowe na remonty i modernizacje placówek ochrony zdrowia.

Ustawa o zakładach opieki zdrowotnej z 1991 r. umożliwiała przekształcenia w podstawowej opiece zdrowotnej oraz kreśliła ramy zmian organizacyjnych, funkcjonalnych i finansowych w jednostkach zamkniętej opieki zdrowotnej $[2,12]$. Zgodnie z treścią ustawy zakład opieki zdrowotnej stanowił wyodrębniony organizacyjnie zespół osób i środków majątkowych, utworzony w celu udzielania świadczeń zdrowotnych, zapobiegania powstawaniu chorób, szerzenia oświaty zdrowotnej i zapewniania możliwości kształcenia kadr medycznych. Ponadto ZOZ-y mogły być powoływane w celu prowadzenia badań naukowych oraz wypełniania zadań dydaktycznych powiązanych z udzielaniem świadczeń zdrowotnych i promocją zdrowia [12]. Spośród zakładów opieki zdrowotnej wymieniało się: szpitale, zakłady opiekuńczo-lecznicze, zakłady pielęgnacyjno-opiekuńcze, sanatoria, prewentoria, zakłady przeznaczone dla osób, których stan zdrowia wymaga udzielania całodobowych świadczeń zdrowotnych, poradnie, przychodnie, ośrodki zdrowia, pogotowie ratunkowe, pracownie diagnostyczne, pracownie protetyki stomatologicznej i ortodoncji, zakłady rehabilitacji leczniczej, żłobki i inne [12]. Funkcjonowanie ZOZ-ów opierało się oprócz wskazań ustawy na statucie, który określał: nazwę zakładu odpowiadającą zakresowi udzielanych świadczeń, cele i zadania zakładu, zakres i rodzaje udzielanych świadczeń, strukturę organizacyjną i organy zakładu $[2,12]$.

Tworzony w ten sposób system opieki zdrowotnej opierał się na wielosektorowym mechanizmie finansowania ZOZ-ów. Wiązało się to również z nazwą powoływanych zakładów. Publiczne zakłady opieki zdrowotnej (PZOZ) otrzymywały środki finansowe z odpłatnych świadczeń zdrowotnych, darowizn, zapisów, spadków oraz dotacji budżetowych. Organem tworzącym PZOZ był centralny lub naczelny organ administracji państwowej, wojewoda lub organy gminy [13]. Niepubliczne zakłady opieki zdrowotnej (NZOZ) były finansowane przez kościół, związki wyznaniowe, pracodawców, zakład ubezpieczeń, stowarzyszenie, inną osobę prawną lub fizyczną oraz spółkę nieposiadającą osobowości prawnej [2].
Reforma służby zdrowia w latach 90. XX w. miała wpływ na przygotowanie się dotychczasowych zakładów opieki zdrowotnej do restrukturyzacji i usamodzielnienia [12]. Wprowadzone na podstawie ustawy z 1991 r. reformy były próbą urynkowienia usług medycznych, zmian w zakresie finansowania opieki zdrowotnej i rozdzielenia funkcji świadczeniobiorcy i płatnika [14]. Głównymi zaletami, jakie miały wynikać z tego typu przeobrażeń, była możliwość samodzielnego dysponowania własnym majątkiem, samodzielnego pozyskiwania kredytów bankowych, które mogły być przeznaczane na poprawę wizerunku, infrastruktury przychodni i poradni, zmiany wyposażenia, sprzętu i materiałów używanych w lecznictwie oraz finansowania szkoleń podnoszących poziom wiedzy i umiejętności kadr medycznych. Jedną ze zmian, które wprowadzała reforma, była zmiana nomenklatury i słownictwa. Nastąpiło przewartościowanie wartości i z lekarza stworzono świadczeniodawcę, z pacjenta świadczeniobiorcę, a z przychodni, poradni czy szpitala - podmiot leczniczy. Cały proces leczniczy przekształcono w zespół świadczeń zdrowotnych w rozumieniu usługowym.

Na podstawie zarządzenia Ministra Zdrowia i Opieki Społecznej z 1995 r. weszła w życie nowatorska koncepcja mówiąca o samodzielności ZOZ-ów, dzięki czemu środki publiczne mogły zostać przekazywane do samodzielnych zakładów opieki zdrowotnej [14].

W celu realizacji świadczeń opieki zdrowotnej w Polsce został zaimplementowany model ubezpieczeniowy finansowania systemu opieki zdrowotnej. Uwarunkowany był on możliwością ochrony ludzi przed nieprzewidywanym zdarzeniem, w tym również chorobą i wynikającymi z niej konsekwencjami utraty bezpieczeństwa materialnego rodziny. Cechami charakterystycznymi modelu ubezpieczeniowego (zwanego również „bismarckowskim”, od inicjatora takiego sposobu finansowania systemu opieki zdrowotnej - kanclerza Rzeszy Niemieckiej Otto von Bismarcka) było finansowanie ubezpieczenia zdrowotnego z obligatoryjnie płaconych przez pracownika i pracodawcę składek, istnienie tzw. kas chorych, które pełniły rolę funduszy ubezpieczeniowych, oraz prawo pacjenta do wolnego wyboru lekarza. Projekty kolejnych zmian w systemie opieki zdrowotnej $[15,16]$ opierały się na zasadach powszechności, obowiązku ubezpieczenia społecznego całego społeczeństwa, solidaryzmu społecznego, samofinansowaniu funduszu ubezpieczeń zdrowotnych i pokryciu wydatków przeznaczonych na inwestycje w publicznych zakładach opieki zdrowotnej ze środków budżetu państwa $[2,15,16]$. Realizacja świadczeń ubezpieczenia zdrowotnego odbywałaby się poprzez powołane do finasowania opieki zdrowotnej instytucje ubezpieczeniowe: Regionalną i Branżową Kasę Powszechnego Ubezpieczenia Zdrowotnego [2,15, 16]. Zwieńczeniem omówionych projektów było uchwalenie przez Sejm w 1997 r. Ustawy o powszechnym ubezpieczeniu zdrowotnym [17]. Jednym z mankamentów przyjętej ustawy było nieuwzględnienie tzw. koszyka świadczeń zdrowotnych.

Nad monitorowaniem i rozliczaniem kontraktów z Regionalną Kasą Chorych czuwały Rejestry Usług Medycznych (RUM), powołane przez Ministra Zdrowia i Opieki Społecznej 
jako system ewidencyjno-informatyczny służący rejestrowaniu usług medycznych $[2,18]$. System RUM, określony jako instytucjonalny, organizacyjny, techniczny sposób rejestrowania usług w ramach systemu opieki zdrowotnej w Polsce, powstał w 1992 r. w Lublinie. Zalecenie jego wdrożenia na terenie całego kraju wydał Komitet Ekonomiczny Rady Ministrów w 1995 r. [18, 19]. W ramach działań legislacyjnych Minister Zdrowia i Opieki Społecznej 1 sierpnia 1996 r. wydał rozporządzenie w sprawie wprowadzenia książeczek usług medycznych, stanowiących podstawę wzajemnego rozliczania świadczeń zdrowotnych pomiędzy świadczeniodawcami a płatnikiem - Regionalną Kasą Chorych (RKCh) lub Branżową Kasą Chorych (BKCh) [19].

W dniu 1 stycznia 1999 r. na podstawie Rozporządzenia Ministra Zdrowia i Opieki Społecznej powstało 17 RKCh i 1 BKCh [20]. Podstawowym celem RKCh było zapewnienie odpowiedniego poziomu świadczeń zdrowotnych na podległym im terenie. W celu realizacji tego zamierzenia racjonalizowała ona wydatkowanie środków finansowych ze składek przekazywanych na ubezpieczenie zdrowotne [20].

W celu zapewnienia kompleksowej opieki zdrowotnej nad ubezpieczonymi RKCh co roku podpisywała umowy na realizację świadczeń zdrowotnych z przychodniami, poradniami specjalistycznymi, szpitalami, klinikami, lekarzami prowadzącymi indywidualne praktyki lekarskie i lekarsko-stomatologiczne, pielęgniarkami i położnymi, aptekami, sanatoriami, zakładami opiekuńczo-leczniczymi i innymi jednostkami, które miały kwalifikacje do udzielania świadczeń zdrowotnych. Wypełniając swoje zadania, RKCh podlegała ujednoliconym dla wszystkich 17 Kas Chorych (KCh) przepisom i delegacjom ustawowym w zakresie praw i obowiązków kontraktowania świadczeń medycznych [20]. Po raz pierwszy w funkcjonowaniu systemu opieki zdrowotnej pojawiła się metoda wyboru realizatorów usług medycznych na zasadzie przeprowadzenia konkursów ofert, negocjacji i podpisywania umów na świadczenie usług medycznych pacjentom ubezpieczonym w KCh. Idea wprowadzenia kontraktacji świadczeń zdrowotnych z założenia słuszna, wiązała się z wprowadzeniem zasad urynkowienia, ekonomizacji i konkurencyjności świadczeniodawców, swobodnego wyboru lekarza i sugerowanego przepływu środków finansowych do lekarzy cieszących się „dobrą opinią” znakomitych specjalistów.

Istniało wiele konfliktów w realizowaniu delegacji ustawowych odnoszących się do przeprowadzania konkursów ofert. Pierwszy wynikał z braku analizy kosztów związanych z realizacją poszczególnych procedur medycznych. Dla KCh wynikały z tego możliwości kontraktowania świadczeń zdrowotnych w poszczególnych dziedzinach z oferentami, którzy dla pozyskania pacjentów zgadzali się na realizację świadczeń zdrowotnych po cenach dumpingowych. Korzystając ze swojej pozycji monopolisty na rynku świadczeń zdrowotnych, KCh określały cenę za poszczególne procedury nie na podstawie liczby świadczeń, które mogły zakupić dla beneficjentów opieki zdrowotnej przy uwzględnieniu realnych kosztów „wytworzenia” danego świadczenia, lecz realizując zasadę konieczności zakupu określonej liczby świadczeń zdrowotnych za przeznaczone na ten cel określone niepodlegające regulacji kwoty. Zapisane w delegacji prawnej negocjacje miały tylko wymiar literalny, bez możliwości przyjęcia stanowiska satysfakcjonującego obie strony postępowania. Będąc monopolistą, KCh skutecznie eliminowały z rynku podmioty, które realizując zasady wolnego rynku, rzetelnie wyceniały koszt wykonania poszczególnych procedur medycznych niemieszczący się w kryteriach przyjętych przez KCh.

Wprowadzany mechanizm rynkowy stworzył odczuwalne ograniczenia popytowe ze strony płatnika - Regionalnej Kasy Chorych [11]. Obniżając kwoty przeznaczone na realizację poszczególnych procedur medycznych ze względu na braki środków finansowych, KCh twardo negocjowały ceny usług medycznych, stawiając wymagania spełnienia przez oferentów dodatkowych warunków. Kwoty przeznaczane na realizację świadczeń zdrowotnych nie były konfrontowane z zapotrzebowaniem lokalnym na świadczenia z danej dziedziny medycyny ani z kosztami świadczeniodawców ponoszonymi w procesie realizacji procesu leczniczego. Regionalne Kasy Chorych, znajdując się na pozycji monopolisty, przy sprzyjającej koniunkturze związanej z potrzebami podmiotów leczniczych, które zamierzały realizować świadczenia zdrowotne w ramach ubezpieczenia zdrowotnego, twardo dyktowały ceny świadczeń zdrowotnych, w nierealnych wysokościach. Część podmiotów, które wycofały się i przeszły do prywatnej działalności w zakresie ochrony zdrowia, spotkała się ze zmniejszeniem popytu ze względu na spadek dochodów ludności, a tym samym spadek środków przeznaczonych na świadczenia prywatnej opieki zdrowotnej [11]. Cechą charakterystyczną był zamknięty charakter systemu opartego na RKCh. Wiązało się to z brakiem możliwości przystąpienia do sytemu świadczeń zdrowotnych finansowanych ze środków publicznych przez podmioty medyczne w dowolnym czasie. Konkursy ofert ogłaszane były najczęściej co 3 lata, a pierwszeństwo w ponownym podpisaniu kontraktu miały podmioty dotychczas współpracujące z RKCh. Możliwość współpracy z płatnikiem publicznym w odrębnych terminach wynikała jedynie z występowania tzw. białych plam na mapie potrzeb zdrowotnych, czyli w miejscach, w których świadczenia nie zostały zakontraktowane w pierwotnym postępowaniu konkursowym.

Próbami przeciwdziałania praktykom monopolistycznym RKCh były negocjacje samorządu lekarskiego z przedstawicielami KCh. Pod auspicjami izb lekarskich stworzono m.in. system wyceny i wartościowania pracy lekarza dentysty. Był to system opracowany przez dra Wojciecha Grabego, w którym wycenę poszczególnych procedur stomatologicznych podano w wartościach punktowych, ujednolicając nakład pracy i środków finansowych przeznaczanych na realizację poszczególnych świadczeń. Ujednolicona w ten sposób punktowa wartość procedur stomatologicznych do realnej wyceny wartości świadczenia stomatologicznego wymagała jedynie wprowadzenia realnego mnożnika finansowego. Wprowadzone w systemie Grabego wysokie standardy, którym powinny odpowiadać świadczenia stomatologiczne, zostały przyjęte przez KCh. Zaczęły one wymagać od lekarzy 
dentystów kompleksowego dostosowywania się do standardów. Jednakże nie pociągnęły za sobą zmiany wyceny świadczeń stomatologicznych poprzez narzucone nierealne do rzeczywistości wartości mnożnika. Powstały w ten sposób system KCh wymuszał na lekarzach dostosowanie się do wysokich standardów świadczenia procedur opieki zdrowotnej wobec braku realnych środków pozyskiwanych na ich realizację ze strony płatnika. Brak solidarności zawodowej w środowisku lekarzy dentystów, którzy dostosowywali się do stawek narzucanych przez KCh, wpływał na systematyczne obniżanie nakładów przeznaczanych na opiekę stomatologiczną i nieopłacalność funkcjonowania w publicznym systemie opieki zdrowotnej. Brak rzetelnej wyceny procedur medycznych przez KCh pozwalał na określanie wartości procedur medycznych na zasadzie pełnej uznaniowości. Jednocześnie w umowach zawieranych z RKCh nie uwzględniano wynagrodzenia personelu. Przekazane finansowanie w myśl umowy miało w pełni zostać wydane na potrzeby pacjenta.

Podsumowując okres reformowania systemu ochrony zdrowia w latach 1989-2000 zapoczątkowany zasadniczymi zmianami ustroju politycznego i gospodarczego, należy stwierdzić, że zmiany źle funkcjonującego systemu opieki zdrowotnej postępowały wolno, co spowodowane było rosnącym niezadowoleniem społecznym. W dodatku chroniczne niedofinansowanie uniemożliwiało podejmowanie jakichkolwiek działań naprawczych mogących zwiększyć dopływ pieniędzy do systemu opieki zdrowotnej. Należy jednak odnotować znaczenie uchwalenia ustawy o zakładach opieki zdrowotnej z 1991 r., która miała zarówno wady, jak i zalety, ale w radykalny sposób zapoczątkowała i przyspieszyła prace nad dalszymi działaniami reformatorskimi.

Trwały prace nad przygotowaniem podstaw merytorycznych do usamodzielnienia zakładów opieki zdrowotnej (z jednostek budżetowych) oraz prace nad projektem ustawy o powszechnym ubezpieczeniu zdrowotnym.

Konsekwencją ustawy o ZOZ było też m.in. wprowadzenie rachunku kosztów w publicznych zakładach opieki zdrowotnej uczestniczących w programie pilotażowo-wdrożeniowym oraz możliwość przejęcia części zadań ochrony zdrowia przez samorządy lokalne.

To ta ustawa była podstawą do przeprowadzenia kolejnych zmian w sektorze zdrowotnym i dotychczas ma priorytetowe znaczenie dla organizacji ochrony zdrowia Polsce.

\section{PIŚMIENNICTWO}

1. Kotuła J. Rozwój lecznictwa stomatologicznego w Zielonej Górze w latach 1945-1989 [dissertation]. Łódź: Uniw. Med. w Łodzi; 2016. p. 5-23.

2. Forgt B. Poznański Ośrodek Rehabilitacyjny w kontekście zmian zachodzących w ochronie zdrowia w latach 1952-2005 [dissertation]. Poznań: Uniw. Med. im. Karola Marcinkowskiego w Poznaniu; 2012. p. 72.

3. Indulski J, Orzeszyna S. Drogi i bezdroża medycyny społecznej w Polsce. Służ Zdr 1981;7:3.

4. Włodarczyk C. Reforma opieki zdrowotnej jako proces polityczny. Kilka uwag o wybranych wątkach. Probl Polit Społ 2002;4:33-57.

5. Golimowska S. System ochrony zdrowia w Polsce po dotychczasowych zmianach. Kraków: Collegium Medicum UJ; 2003.

6. Raport Konserwatorium „Doświadczenie i Przyszłość”. Stan zdrowia i ochrony zdrowia ludności Polski. Życie i Nowoczesność, 2.04.1981.

7. Indulski J, Gulewicz T, Szymborski L, Włodarczyk C. Opieka zdrowotna w Polsce. Próba oceny i kierunki usprawnień. Zdrow Publiczne 1981;11:750-5.

8. Krasucki P. Założenia reformy ochrony zdrowia. Służ Zdr 1981;48:5.

9. Rozporządzenie Ministra Zdrowia i Opieki Społecznej z dnia 2 maja 1989 r. zmieniające rozporządzenie w prawie organizacji i zadań zakładów opieki zdrowotnej. DzU z 1989 r., nr 28, poz. 152.

10. Ustawa z dnia 2 maja 1990 r. o podziale zadań i kompetencji określonych w ustawach szczegółowych pomiędzy organy gminy a organy administracji rządowej oraz o zmianie niektórych ustaw. DzU z 1990 r., nr 34, poz. 198.

11. Golinowska St. Opieka zdrowotna w Polsce po reformie. Warszawa: Centrum Analiz Społeczno-Ekonomicznych; 2002.p. 440-5.

12. Ustawa z dnia 30 sierpnia 1991 r. o zakładach opieki zdrowotnej. DzU z 1991 r., nr 91, poz. 408.

13. Dzwonkowski T, Skobelski R, Szczegóła H. Szpital Wojewódzki im. Karola Marcinkowskiego w Zielonej Górze (1945-2015). Zielona Góra: Pro Libris; 2015. p. 151.

14. Zarządzenie Ministra Zdrowia i Opieki Społecznej z dnia 18 maja 1995 r. w sprawie warunków, na jakich następuje przekazanie środków publicznych do samodzielnych publicznych zakładów opieki zdrowotnej oraz sposobu kontroli ich wykorzystania. M.P. 1995, nr 29, poz. 341.

15. Hady J, Leśniowska M. Finansowanie polskiego systemu opieki zdrowotnej na tle wybranych krajów Unii Europejskiej, https://rf.gov.pl/ files/20725_5260__Joanna_Hady__Malgorzata_Lesniowska_-_Finansowanie_polskiego_systemu_opieki_zdrowotnej_na_tle_wybranych_krajow_Unii_Europ.pdf (10.03.2017).

16. Kautsch M, Whitfield M, Klich J, editors. Zarządzanie w opiece zdrowotnej. Kraków: Wyd. UJ; 2001.p. 33.

17. Ustawa z dnia 6 lutego 1997 r. o powszechnym ubezpieczeniu zdrowotnym. DzU z 1997 r., nr 28, poz. 153, 1107-32.

18. Pierożek ZJ. Rejestr Usług Medycznych - strategiczne narzędzie analityczne w polskim systemie ochrony zdrowia [dissertation]. Lublin: Akad. Med. w Lublinie; 2002. p. 10-1.

19. Rozporządzenie Ministra Zdrowia i Opieki Społecznej z dnia 27 czerwca 1996 r. w sprawie książeczek usług medycznych. DzU z 1996 r., nr 2, poz. 420.

20. Rozporządzenie Ministra Zdrowia i Opieki Społecznej z dnia 7 grudnia 1998 r. w sprawie utworzenia regionalnych Kas Chorych i ich oddziałów, określenia ich siedzib i obszaru działania oraz nadania im statutów. DzU z 1998 r., nr 152, poz. 989. 